\title{
Isoflavones content in soybean and soybean milk in Rwanda
}

\author{
M. Niyibituronsa ${ }^{1,2,3}$, A.N. Onyango ${ }^{2}$, S. Gaidashova ${ }^{1}$, S. Imathiu $^{2}$, M. Uwizerwa ${ }^{1}$, I. Wanjuki ${ }^{3}$, \\ F. Munga ${ }^{3}$, E. Ochieng ${ }^{3}$, J. Birungi ${ }^{3}$, S. Ghimire ${ }^{3}$, S. Mutiga ${ }^{3,4}$ and J. Harvey ${ }^{3,4}$ \\ ${ }^{1}$ Rwanda Agriculture Board, Rwanda, \\ ${ }^{2}$ Jomo Kenyatta University of Agriculture and Technology, Kenya, \\ ${ }^{3}$ Biosciences eastern and central Africa-International Livestock Research Institute Hub, Kenya and \\ ${ }^{4}$ Kansas State University, USA
}

The most important attribute of soybean is their health benefits due to protein and isoflavones that prevent and treat many chronic diseases $^{(1)}$. Isoflavones found in soybean have anti-carcinogenetic activities, prevent cardio-vascular diseases, prevent osteoporosis, have antioxidant activities and alleviate menopausal symptoms ${ }^{(2)}$. The countries with highest consumption of phyto-oestrogen (isoflavone and lignan) have low rate of breast cancer ${ }^{(3)}$. However there is limited information on isoflavones content in soybean produced in Rwanda. The study aimed to determine isoflavones content in soybean varieties grown in Rwanda and soybean milk processed using water extraction method ${ }^{(4)}$.

Isoflavones were determined in five varieties grown in South and Eastern zones using AOAC Official Method 2008.03 ${ }^{(5)}$. Triplicates samples of soybean flour $(\mathrm{N}=10)$ and soybean milk $(\mathrm{N}=10)$ were used for study. The extracts analysed on a reverse-phase $(\mathrm{C}-18)$ UPLC with UV detection $\left(\lambda_{\mathrm{nm}}=260\right)$. The target analytes were aglycon isoflavones: Genistein and Daidzein, and their glucoside forms: Daidzin and Genistin.

\begin{tabular}{|c|c|c|c|c|c|c|c|c|c|}
\hline Sample & Daidzin & SD & Genistin & SD & Daidzein & SD & Genistein & SD & Total \\
\hline PEKA6 & 918.7 & $58 \cdot 0$ & $1209 \cdot 8$ & $32 \cdot 1$ & $26 \cdot 0$ & 1.9 & $5 \cdot 7$ & $0 \cdot 4$ & $2160 \cdot 2$ \\
\hline SAGA & $857 \cdot 1$ & $19 \cdot 2$ & 1114.4 & $38 \cdot 8$ & $9 \cdot 0$ & $0 \cdot 3$ & $7 \cdot 1$ & $0 \cdot 5$ & $1987 \cdot 6$ \\
\hline SEQUEL & $843 \cdot 0$ & 57.5 & $1011 \cdot 6$ & 31.4 & $8 \cdot 1$ & 1.9 & $3 \cdot 6$ & $0 \cdot 1$ & $1866 \cdot 2$ \\
\hline SQUIRE & $2296 \cdot 3$ & $196 \cdot 7$ & $2260 \cdot 7$ & 57.6 & $40 \cdot 9$ & $3 \cdot 7$ & $29 \cdot 0$ & 1.7 & $4627 \cdot 0$ \\
\hline SB24 & $1245 \cdot 2$ & $26 \cdot 3$ & $1004 \cdot 6$ & 34.7 & $15 \cdot 1$ & 0.9 & $7 \cdot 4$ & $1 \cdot 3$ & $2272 \cdot 3$ \\
\hline \multicolumn{10}{|c|}{ Isoflavones content $(\mu \mathrm{g} / \mathrm{g})$ in soybean milk } \\
\hline PEKA6 & $71 \cdot 0$ & $0 \cdot 9$ & $88 \cdot 8$ & $3 \cdot 6$ & $9 \cdot 6$ & $0 \cdot 3$ & $8 \cdot 4$ & $0 \cdot 2$ & $177 \cdot 8$ \\
\hline SAGA & $61 \cdot 0$ & $6 \cdot 3$ & $81 \cdot 7$ & $8 \cdot 8$ & 8.8 & $1 \cdot 0$ & $11 \cdot 3$ & $0 \cdot 8$ & $162 \cdot 8$ \\
\hline SEQUEL & $66 \cdot 0$ & $3 \cdot 6$ & $85 \cdot 3$ & $6 \cdot 2$ & $9 \cdot 2$ & $0 \cdot 6$ & $9 \cdot 8$ & $0 \cdot 5$ & $170 \cdot 3$ \\
\hline SQUIRE & $117 \cdot 1$ & $2 \cdot 4$ & $124 \cdot 4$ & $4 \cdot 6$ & $18 \cdot 1$ & $0 \cdot 7$ & $17 \cdot 8$ & $0 \cdot 3$ & $277 \cdot 5$ \\
\hline SB24 & $76 \cdot 7$ & $11 \cdot 0$ & $54 \cdot 2$ & $6 \cdot 4$ & $6 \cdot 1$ & $0 \cdot 8$ & $3 \cdot 1$ & 0.4 & $140 \cdot 1$ \\
\hline
\end{tabular}

The total isoflavones varied between $1866 \cdot 2$ and $4627 \cdot 0 \mu \mathrm{g} / \mathrm{g}$ in soybean flour and between $140 \cdot 1$ and $277 \cdot 5 \mu \mathrm{g} / \mathrm{g}$ for soybean milk. Squire variety had the highest isoflavone content with twice more than the other test varieties in both flour and milk. These findings will inform Rwandese breeders on how best to adjust their programs in order to improve the nutritional content of cultivated soybean and the Rwandan wellbeing.

This project was supported by the BecA-ILRI Hub through the Africa Biosciences Challenge Fund (ABCF) program.

1. Jooyandeh H (2011) MEJSR 7(1) 71-80.

2. Alekel D L, St Germain A, Peterson C T et al. (2000) Am $J$ Clin Nutr 72, 844-852.

3. Anderson L N, Michelle Cotterchio M et al.(2013) IJC 132(7), 1683-1692.

4. Hosken B (1999) reviewed by Lui, KeShun, Aspen Pub Inc. Maryland.

5. AOAC (2008) J. AOAC International, 91(3): m489-500. 